\title{
TINGKAT BUNGA DAN NILAI LARANGAN DALAM AL-QURAN TERHADAP KINERJA BANK SYARIAH
}

\section{Syarifah Febrianti ${ }^{1}$, Hasanuddin ${ }^{2}$}

${ }^{1}$ Universitas Muhammadiyah Makassar \|

${ }^{2}$ Prodi Hukum Ekonomi Syariah Unismuh Makassar || hasanuddiningka@gmail.com

\begin{abstract}
Abstrak
Penelitian ini termasuk penelitian kuantitatif yang bertujuan untuk mengetahui apakah tingkat bunga berpengaruh terhadap kinerja Bank BNI Syariah Cabang Makassar dan telah sesuai dengan nilai larangan dalam $\mathrm{Al}$ Quran. Dalam penelitian ini terdiri dari tiga variabel, yaitu X1 Tingkat Bunga, X2 Nilai Larangan dalam Al Quran, dan Y Kinerja BNI Syariah.

Total sampling dalam penelitian ini berjumlah 100 orang. Pengumpulan data dilakukan dengan cara penyebaran kuesioner atau angket. Adapun yang menjadi populasi dalam penelitian ini adalah jumlah nasabah dan karyawan Bank BNI Syariah Cabang Makassar sebanyak 18,250 orang, dengan menggunakan rumus Sloving maka menghasilkan sampel sebanyak 100 sampel. Selanjutnya, data yang diperoleh melalui instrumenttersebut kemudian diolah melalui analisis regresi linear berganda dengan bantuan aplikasi Partial Least Square (PLS).

Hasil penelitian menunjukkan bahwa margin syariah, penjualan hasil pertanian, agen dan kesejahteraan keluarga petani berpegaruh positif dan signifikan dari hasil analisis inferensial yang menggunakan uji t dengan rumus regresi linear berganda menunjukkan bahwa nilai t hitung lebih besar dari pada nilai $t$ tabel.
\end{abstract}

Kata Kunci: Tingkat Bunga, Nilai Larangan, Kinerja 


\title{
J-HES
}

Jurnal Hukum Ekonomi Syariah

Volume 2, No. 2, Juli-Desember 2018 | p-ISSN: 2549-4872 | e-ISSN: 2654-4970

\begin{abstract}
This study includes quantitative research that aims to determine whether the interest rate affects the performance of the Makassar Branch Bank BNI Syariah and is in accordance with the prohibition value in the Qur'an. In this study consists of three variables, namely X1 Interest Rate, X2 Value of Prohibition in the Quran, and Y Performance of BNI Syariah.

The total sampling in this study amounted to 100 people. Data collection was done by distributing questionnaires or questionnaires. As for the population in this study is the number of customers and employees of Bank BNI Syariah Makassar Branch as many as 18,250 people, using the Slovin formula then produces a sample of 100 samples. Furthermore, the data obtained through these instruments are then processed through multiple linear regression analysis with the help of a Partial Least Square (PLS) application.

The results showed that the margin of sharia, sales of agricultural products, agents and family welfare of farmers had a positive and significant effect from the results of inferential analysis using the t-test with the formula of multiple linear regression indicating that the tcount value was greater than the value of t table.
\end{abstract}

Keywords: Interest Rate, Prohibition Value, Performance

\section{PENDAHULUAN}

Perbankan syariah di Indonesia, pertama kali dipelopori oleh Bank Muamalat Indonesia (BMI) yang berdiri pada tahun 1991. Bank ini pada awal berdirinya di prakarsai oleh Majelis Ulama Indonesia (MUI) dan pemerintah serta mendapat dukungan dari Ikatan Cendekiawan Muslim Indonesia (ICMI) dan beberapa pengusaha muslim. Pada saat krisis moneter yang terjadi pada akhir 1990, bank ini mengalami kesulitan sehingga ekuitasnya hanya tersisa sepertiga dari modal awal. Islamic Development Bank (IDB) kemudian memberikan suntikan dana pada bank ini dan pada periode 1999-2002 dapat bangkit dan menghasilkan laba. Hingga tahun 2007 terdapat 3 institusi bank syariah di Indonesia yaitu Bank Muamalat Indonesia (BMI), Bank Syariah Mandiri (BSM) dan Bank Mega Syariah. Sementara itu, bank umum yang telah meiliki Unit Usaha Syariah (UUS) adalah 19 bank di antaranya merupakan bank besar seperti Bank Negara Indonesia dan Bank Rakyat Indonesia (BRI). Prinsip kerja bank syariah adalah aturan perjanjian berdasarkan hokum Islam antara bank dan pihak lain untuk penyimpanan dana dan atau pembiayaan kegiatan usaha atau kegiatan lainnya yang sesuai dengan syariah. 
Kehadiran BSM sejak tahun 1999, sesungguhnya merupakan hikmah sekaligus berkah pasca krisis ekonomi dan moneter 1997-1998. Sebagaimana diketahui, krisis ekonomi dan moneter sejak juli 1997, yang disusul dengan kritis multi-dimensi termasuk di panggung politik nasional, telah menimbulkan beragam dampak negatif yang sangat hebat terhadap seluruh sendi kehidupan masyarakat, tidak terkecuali dunia usaha. Dalam kondisi tersebut, industri perbankan nasional yang didominasi oleh bankbank konvensional mengalami krisis luar biasa. Pemerintah akhirnya mengambil tindakan dengan merestrukturisasi dan merekapitalisasi sebagian bank-bank di Indonesia.

Pada saat itu, pemerintah melakukan penggabungan (merger) empat bank (Bank Dagang Negara, Bank Bumi Daya, Bank Exim dan Bapindo) menjadi satu bank baru bernama PT. Bank Mandiri (Persero) pada tanggal 31 Juli 1999. Kebijakan penggabungan tersebut juga menempatkan dan menetapkan PT. Bank Mandiri (Persero) Tbk. sebagai pemilik mayoritas baru Branch State Bank (BSB).
PT. Bank Syariah Mandiri hadir, tampil dan tumbuh sebagai bank yang mampu memadukan idealisme usaha dengan nilai-nilai rohani yang melandasi operasionalnya. Harmoni antara idealisme usaha dan nilai-nilai rohani inilah yang menjadi salah satu keunggulan Bank Syariah Mandiri dalam kiprahnya di perbankan Indonesia. BSM hadir untuk bersama membangun Indonesia menuju Indonesia yang lebih baik.

Kebijakan yang dikeluarkan pemerintah pada saat itu menaikan tingkat suku bunga pada krisis moneter tahun 1997 mengakibatkan sejumlah bank konvensional goncang dan akhirnya dilikuidasi karena mengalami negativespread. Hal ini terjadi karena bank harus membanyar bunga simpanan nasabah yang jauh lebih tinggi dari pada bunga kredit yang diterimanya dari debitur.

Sedangkan perbankan Syariah terbebas dari negative spread, karena perbankan syariah tidak berbasis pada bunga uang. Konsep Islam adalah menjaga keseimbangan antara sektor riil dengan sektor moneter, sehingga pertumbuhan pembiayaan tidak lepas dari pertumbuhan sektor riil yang 
dibiayainya. Dengan kata lain, kinerja perbankan Islam ditentukan oleh kinerja sektor riil, dan bukan sebaliknya. Dalam pandangan Islam, uang hanyalah sebagai alat tukar dan bukan merupakan barang dan komoditas. Dalam perkonomian Indonesia ketika adanya kenaikan tingkat suku bunga pada bank-bank umum (konvensional) akan mempengaruhi peran intermediasi dunia perbankan. Dalam operasional perbankan konvensional sangat tergantung pada tingkat suku bunga yang berlaku, karena keuntungan bank konvensional berasal dari selisih antara bunga pinjaman dengan bunga simpanan. Sedangkan dalam perbankan syariah tidak mengenal sistem bunga tapi yang ada adalah prinsip profit sharing antara bank dengan nasabah dalam pengelolaan dananya. Berdasarkan uraian diatas mengenai penabung atau deposan bersifat motif keuntungan adalah dilihat dari segi tingkat suku bunga bank konvensional, jika tingkat suku bunga lebih tinggi dari tingkat bagi hasil maka nasabah memilih untuk menyimpan dananya di bank konvensional dan sebaliknya jika tingkat bagi hasil lebih besar dari tingkat suku bunga maka nasabah memilih untuk mendepositokan dananya dari pada menabung tabungan biasa, dengan alasan bahwa keuntungan yang didapat adalah lebih besar walaupun memang risiko yang dihadapi cukup besar.

\section{METODE PENELITIAN}

\section{A. Jenis Pendekatan, Desain dan}

\section{Metode Penelitian}

Dalam penelitian ini, peneliti menggunakan jenis pendekatan penelitian deskriptif kuantitatif, yaitu peneliti yang menjelaskan pengaruh antara variabel- variabel pengujian hipotesis.

Merancang pemenuhan pengaruh tingkat bunga, dengan masukan hasil penelitian melalui metode pengamatan, survey, wawancara serta kuesioner dalam populasi/sampel dengan menggunakan metode SEM (Structural Equation Modeling) dapat memberikan jawaban atas kasus.

\section{B. Metode Analisis Data}

Analisis data dilakukan dengan cara analisis kuantitatif dengan menggunakan metode Partial Least Square (PLS), yaitu suatu metode yang 
berbasiskeluargaregresi

yang

dikenalkan oleh Herman O. A Wold

untuk penciptaan dan pembangunan

model dan metode untuk ilmu-ilmu

social dengan pendekatan yang berorientasi pada prediksi. PLS memiliki asumsi data penelitian bebas distribusi (Distribution-Free), artinya data penelitian tidak mengacuh pada salah satu distribusi tertentu (misalnya distribusi normal).

PLS merupakan metode alternative dari Structural Equation Modeling (SEM) yang dapat digunakan untuk mengatasi permasalahan hubungan diantara variabel yang kompleks namun ukuran sampel datanya kecil (30 sampai 100), mengingat SEM memilki ukuran sampel data minimal (Hair et.al., 2010). PLS digunakan untuk mengetahui kompleksitas hubungan suatu konstrak dan konstrak yang lain, serta hubungan suatu konstrak dan indikator-indikatornya.

PLS didefenisikan oleh dua persamaan, yaitu inner model dan outer model. Inner model menentukan spesifikasi hubungan antara suatu konstrak dan konstrak yang lain, sedangkan outer model menentukan spesifikasi hubungan antara konstrak dan indikator-indikatornya.

\section{HASIL DAN PEMBAHASAN}

\section{A. Analisis Data}

$$
\text { Model analisis yang }
$$

dipergunakan dalam penelitian ini adalah analisis yang diperoleh dari Pengaruh Tingkat Bunga Dan Nilai Larangan Dalam Terhadap Kinerja Bank BNI Syariah Cabang Makassar dan diolah dengan menggunakan Partial Least Square - Partial Modeling (PLS-PM). Depenelitian Variabel Penelitian, yaitu :

1. Tingkat Bunga $(\xi)$

Tabel 1 Tingkat Bunga

\begin{tabular}{|c|c|c|c|c|c|c|}
\hline \multirow{2}{*}{ No } & \multirow{2}{*}{ Indikator } & \multicolumn{5}{|c|}{ Pernyataan } \\
\hline & & 5 & 4 & 3 & 2 & 1 \\
\hline 1. & $\mathrm{X} 1$ (Investasi) & 56 & 43 & 1 & - & - \\
\hline 2. & $\mathrm{X}_{2}$ (Pertambahan Nilai) & 41 & 57 & 2 & - & - \\
\hline 3. & X3 (Mendorong Konsumen Untuk Menabung) & 58 & 42 & - & - & - \\
\hline 4. & $\mathrm{X}_{4}$ (Keseimbangan) & 52 & 48 & - & - & - \\
\hline
\end{tabular}


Kesimpulan:

Untuk X1 (Investasi) yang memilih dengan kategori setuju $=56$ indikator ini mampu mepengaruhi variabel tingkat bunga.

Untuk X2 (Pertambahan Nilai) yang memilih dengan kategori setuju $=57$ indikator ini mampu mempengaruhi variabel tingkat bunga.

2. Nilai Larangan dalam Al Quran ( $\beta)$
Untuk X3 (Mendorong Nasabah Untuk Menabung) yang memilih dengan kategori setuju $=58$ indikator ini mampu mempengaruhi variabel tingkat bunga.

Untuk X4 (Keseimbangan) yang memilih dengan kategori setuju $=52$ indikator ini mampu mempengaruhi variabel tingkat bunga.

Tabel 2 Nilai Larangan dalam Al Quran

\begin{tabular}{clrrrrr}
\hline \multirow{2}{*}{ No } & \multirow{2}{*}{ Indikator } & \multicolumn{5}{c}{ Pernyataan Responden } \\
\cline { 3 - 7 } & & 5 & 4 & 3 & 2 & 1 \\
\hline 1. & X5 (Riba Nasiah) & 28 & 68 & 4 & - & - \\
\hline 2. & X6 (Riba Fadhl) & 37 & 56 & 6 & 1 & - \\
\hline 3. & X7 (Bunga) & 32 & 63 & 5 & - & - \\
\hline
\end{tabular}

Kesimpulan:

Untuk X6 (Riba Nasiah) yang memilih dengan kategori setuju $=68$ indikator ini mampu mempengaruhi variable nilai larangan dalam Al Quran.

Untuk X7 (Riba Fadhl) yang memilih dengan kategori setuju $=56$ indikator ini mampu mempengaruhi variabel nilai arangan dalam Al Quran.

Untuk X8 (Bunga) yang memilih dengan kategori setuju $=63$ indikator ini mampu mempengaruhi variabel nilai larangan dalam Al Quran.

3. Kinerja BNI Syariah ( $($ )

Tabel 3 Kinerja BNI Syariah

\begin{tabular}{lllllll}
\hline No & \multirow{2}{*}{ Indikator } & \multicolumn{5}{c}{ Pernyataan Responden } \\
\cline { 3 - 7 } & & 5 & 4 & 3 & 2 & 1 \\
\hline 1 & Y1 (Komitmen Organisasi) & 29 & 68 & 3 & - & - \\
\hline 2 & Y2 (Kemadirian) & 65 & 35 & - & - & - \\
\hline 3 & Y3 (Efektivitas) & 48 & 51 & 1 & - & - \\
\hline
\end{tabular}

Kesimpulan:

Untuk Y1 (Komitmen Organisasi) yang memilih dengan kategori setuju $=68$ indikator ini mampu mempengaruhi variabel kinerja BNI Syariah. 
Untuk Y2 (Kemandirian) yang memilih dengan kategori setuju $=65$ indikator ini mampu mempengaruhi variabel kinerja BNI Syariah.

Untuk Y3 (Efektivitas) yang memilih dengan kategori setuju $=51$ indikator ini mampu mempengaruhi variabel kinerja BNI Syariah.

\section{a. Uji Validitas dan Realibilty}

Diperoleh nilai validasi dan realibiliti digunakan composite realibility

D. G. rho dengan nilai diatas $0,70(>0,70)$ nlai larangan dalam $\mathrm{Al}$ Quran 0,900>0,70 jadi data tersebut cukup reliabiliti. Untuk nilai validasi digunakan cronback alpha dengan nilai $(0,5)$ digunakan 0,900 cukup valid.

Variabel Tingkat Bunga D.G rho $0,870>0,70$ validasi reliabiliti. Kinerja
BNI Syariah : dengan nilai P C A namber $=0,756>0,70$ valid dan realibiliti.

b. Uji Model Assesment (Penilaian)

Pengujian atau pemeriksaan selanjutnya dengan melihat nilai AVE (Average Variabel Extrated) yaitu menggambarkan besaran varian yang mampu dijelaskan oleh item-item dibandingkan varian yang disebabkan oleh error pengukuran. Standarnya adalah, bila nilai AVE (Average Variabel Extrated) di atas 0,50 maka dapat dikatakan bahwa variabel memiliki Convergent Validity yang baik berdasarkan loading factor 3 pada (Model Assesment). Nilai AVE untuk variabel:

Tabel 4 Model Assesment (Dimension 1)

\begin{tabular}{|c|c|c|c|c|c|c|c|}
\hline Latent variable & Type & $\begin{array}{c}\text { Mean } \\
\text { (Manifest } \\
\text { variables) }\end{array}$ & $\mathrm{R}^{2}$ & $\begin{array}{l}\text { Adjusted } \\
\mathrm{R}^{2}\end{array}$ & $\begin{array}{c}\text { Mean } \\
\text { Communalities } \\
\text { (AVE) }\end{array}$ & $\begin{array}{c}\text { Mean } \\
\text { Redundancies }\end{array}$ & D.G. rho \\
\hline $\begin{array}{l}\text { NILAI } \\
\text { LARANGAN }\end{array}$ & Exogenous & 0.000 & & & 0.748 & & 0.899 \\
\hline TINGKAT BUNGA & Endogenous & 0.000 & 0.173 & 0.173 & 0.621 & 0.107 & 0.867 \\
\hline $\begin{array}{l}\text { KINERJA BNI } \\
\text { SYARIAH }\end{array}$ & Endogenous & 0.000 & 0.478 & 0.473 & 0.485 & 0.232 & 0.728 \\
\hline Mean & & & 0.326 & & 0.618 & 0.170 & \\
\hline
\end{tabular}

Sumber: data olah dengan menggunakan PLS-PM 
Berdasarkan tabel 4 di atas dapat dilihat bahwa nilai AVE (Average Variable Extrated) dari masing-masing variabel untuk Tingkat Bunga 0,621, Nilai Larangan Dalam Al Quran 0,748, Kinerja BNI Syariah 0,485. Dari data tersebut terlihat bahwa terdapat satu variabel (tngkat bunga) yang lebih besar dari 0,5 maka sifatnya convergent validity yang baik.

Pemeriksaan berikutnya adalah nilai descriminant validity dari model pengukuran reflektif $(\bigcirc)$ yang dimiliki berdasarkan Cross Loading dan membandingkan antara nilai AVE dengan kuadrat korelasi antara variabel. Desriminant validity yang baik akan mampu menjelaskan varian indikatornya lebih tinggi dibandingkan dengan menjelaskan varian dari indikator variabel lainnya.

\section{c. Descriminant Validity}

Descriminant validity dilakukan untuk memastikan bahwa setiap konsep dari masing-masing variabel laten berbeda dengan variabel lainnya. Model mempunyai descriminant validity yang baik jika setiap nilai loading dari setiap indikator dari sebuah variabel laten memiliki nilai loading yang paling besar dengan nilai loading lain terhadap variabel laten lainnya.

Descriminant validity dalam Partial Least Square - Parth Modeling (PLS-PM) dilihat dari dua out - put, yaitu nilai cross loading dan perbandingan nilai AVE dengan kuadrat korelasi antar variabel. Cross Loading menggambarkan korelasi antar suatu indikator dengan variabelnya dan dengan variabel lainnya.

Jika nilai variabel dengan item pengukuran (setiap indikatornya) lebih tinggi dari korelasi dengan indikator dari korelasi dengan indicator dari variabel lainnya. Maka hal ini menunjukkan variabel laten tersebut mampu memprediksi indikatornya dengan lebih baik dari pada variabel lainnya, sekarang kita lihat Cross Loading (Monofacturial Manifest Variables) yaitu hasil pengujian discriminant validity diperoleh sebagai berikut: 
Tabel 5 Cross Loading (Manofactorial Manifest Variables)

\begin{tabular}{cccc}
\hline & $\begin{array}{c}\text { Tingkat Bunga } \\
\text { al- Qur'an }\end{array}$ & \multicolumn{2}{c}{$\begin{array}{c}\text { Nilai Larangan dalam } \\
\text { Sinerja BNI }\end{array}$} \\
\hline X1 & $\mathbf{0 . 7 1 8}$ & $\mathbf{0 . 2 6 2}$ & $\mathbf{0 . 3 4 4}$ \\
\hline X2 & $\mathbf{0 . 7 6 8}$ & $\mathbf{0 . 3 0 0}$ & $\mathbf{0 . 3 3 0}$ \\
\hline X3 & $\mathbf{0 . 8 5 5}$ & $\mathbf{0 . 3 6 2}$ & $\mathbf{0 . 3 9 7}$ \\
\hline X4 & $\mathbf{0 . 8 0 4}$ & $\mathbf{0 . 3 6 6}$ & $\mathbf{0 . 3 8 9}$ \\
\hline X5 & $\mathbf{0 . 4 2 5}$ & $\mathbf{0 . 8 8 5}$ & $\mathbf{0 . 6 2 3}$ \\
\hline X6 & $\mathbf{0 . 2 9 0}$ & $\mathbf{0 . 8 6 6}$ & $\mathbf{0 . 4 9 8}$ \\
\hline X7 & $\mathbf{0 . 3 5 9}$ & $\mathbf{0 . 8 4 4}$ & $\mathbf{0 . 5 8 8}$ \\
\hline Y1 & $\mathbf{0 . 3 8 1}$ & $\mathbf{0 . 6 8 9}$ & $\mathbf{0 . 8 9 5}$ \\
\hline Y2 & $\mathbf{0 . 2 4 7}$ & $\mathbf{0 . 2 1 5}$ & $\mathbf{0 . 5 2 6}$ \\
\hline Y3 & $\mathbf{0 . 3 5 8}$ & $\mathbf{0 . 2 9 0}$ & $\mathbf{0 . 6 1 4}$ \\
\hline
\end{tabular}

Sumber: data olag dengan menggunakan PLS-PM

Berdasarkan tabel diatas dapat $\mathrm{X}_{1}=0,718, \mathrm{X}_{2}=0,768, \mathrm{X}_{3}=0,855$, dilihat bahwa nilai indikator yang $X_{4}=0,804$. Nilai dari indikator $X_{1}, X_{2}$, memiliki korelasi dengan variabel $\mathrm{X}_{3}$, dan $\mathrm{X}_{4}>0,5$.

Tingkat bunga, dimana nilai d. Inner Model (Pengujian Model standardized loading untuk indikator Struktural)

Tabel 6 Path Coefficients (Nilai Larangan Dalam Al Quran/1) $\mathrm{R}^{2}$ (TINGKAT BUNGA / 1):

\begin{tabular}{|c|c|c|c|c|c|c|c|}
\hline $\mathrm{R}^{2}$ & $\mathrm{~F}$ & $\operatorname{Pr}>F$ & $\mathrm{R}^{2}$ (Bootstrap) & Standard error & $\begin{array}{l}\text { Critical ratio } \\
\text { (CR) }\end{array}$ & $\begin{array}{l}\text { Lower bound } \\
\qquad(95 \%)\end{array}$ & $\begin{array}{c}\text { Upper bound } \\
(95 \%)\end{array}$ \\
\hline 0.173 & 20.525 & 0.000 & 0.191 & 0.067 & 2.591 & 0.076 & 0.372 \\
\hline
\end{tabular}

Path coefficients (TINGKAT BUNGA / 1):

\begin{tabular}{|c|c|c|c|c|c|c|c|c|}
\hline Latent variable & Value & $\begin{array}{l}\text { Standard } \\
\text { error }\end{array}$ & $\mathrm{t}$ & $\begin{array}{c}\operatorname{Pr}> \\
|t|\end{array}$ & $\mathrm{f}^{2}$ & $\begin{array}{c}\text { Value } \\
\text { (Bootstrap) }\end{array}$ & $\begin{array}{l}\text { Standard error } \\
\text { (Bootstrap) }\end{array}$ & $\begin{array}{c}\text { Critical } \\
\text { ratio }(\mathrm{CR})\end{array}$ \\
\hline $\begin{array}{l}\text { Nilai } \\
\text { Larangan dalam al- } \\
\text { Qur'an }\end{array}$ & 0.416 & 0.092 & 4.530 & 0.000 & 0.209 & 0.430 & 0.076 & 5.494 \\
\hline
\end{tabular}

Sumber : data olah dengan menggunakan PLS-PM

Berdasarkan tabel path Rasio (CR) 2.591 sehingga dapat coefficients nilai statistik variabel dikatakan bahwa $2.591<5.494$ tingkat bunga dimana nilai $\mathrm{t}$ hitung bahwa tingkat bunga mempengaruhi sebesar 4.530 dengan $\mathrm{R}$ Value 0,416 secara signifikan dan positif terhadap bahwa dengan standar probability variabel nilai larangan dalam Al Quran. $0,076>0,05$ atau dari nilai Critical 
Tabel 7 Path Coefficients (Kinerja BNI Syariah/1) $\mathrm{R}^{2}$ (KINERJA BNI SYARIAH /1):

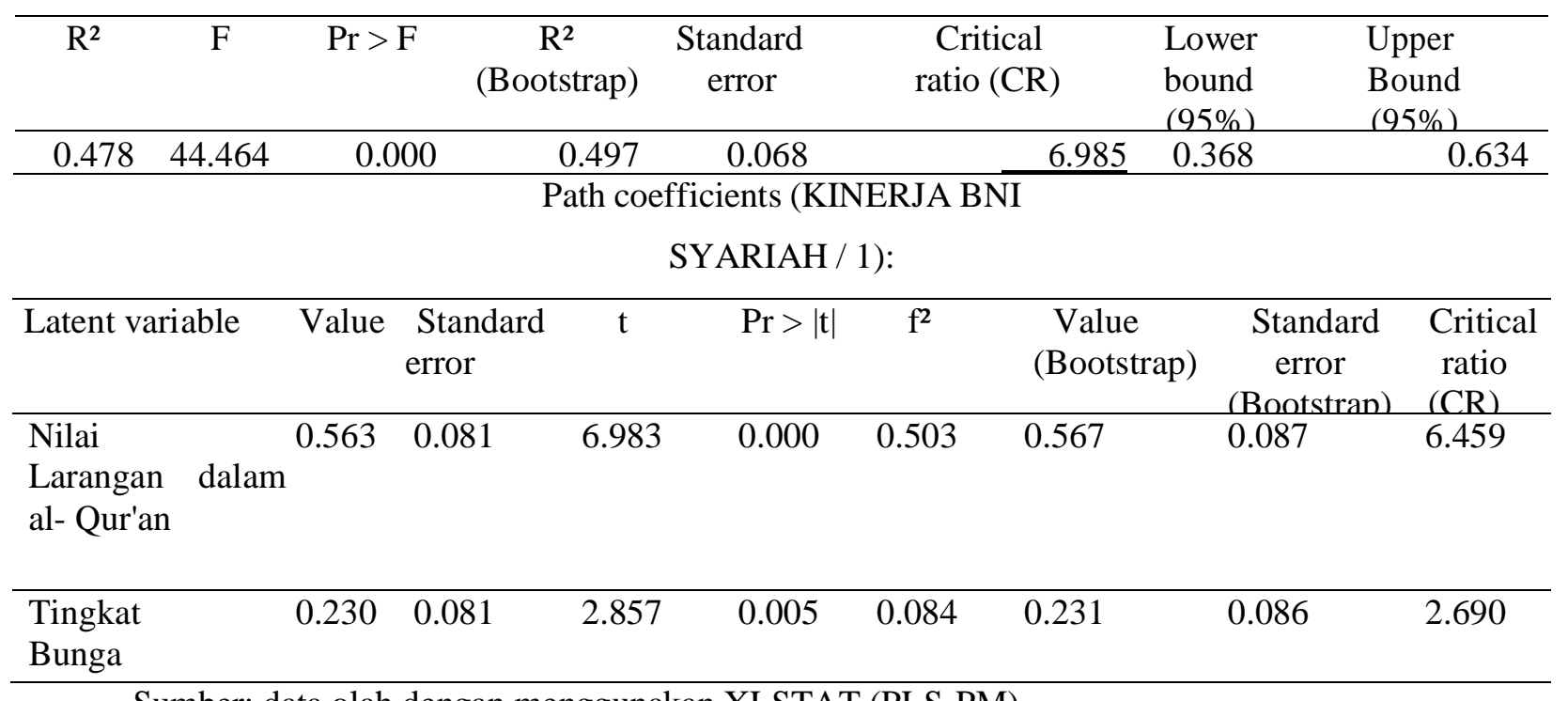

Sumber: data olah dengan menggunakan XLSTAT (PLS-PM)

Berdasarkan table diatas bahwa variable tingkat bunga mempegaruhi variabel kinerja BNI Syariah yaitu sebesar 6,983 signifikan pada $0.05(\mathrm{t}$ hitung lebih besar dari 1,671). Hal ini berarti variabel tingkat bunga memiliki hubungan positif dan signifikan pada variabel kinerja BNI Syariah, pengambilan keputusan mempengaruhi variabel kinerja BNI Syariah yaitu sebesar 2,857 signifikan pada 0,05 (t hitung lebih besar dari 1,671) hal ini berarti variable nilai larangan dalam AlQuran memiliki hubungan positif dan signifikan pada variabel kinerja BNI Syariah.

\section{Jawaban Hasil Penelitian}

\section{a. Hipotesis 1: Tingkat bunga berpengaruh terhadap nilai larangan dalam Al-Qur'an}

Hasil pengujian outer model yang telah dilakukan menunjukkan bahwa variabel tingkat bunga dapat mempengaruhi variabel kinerja $\mathrm{BNI}$ Syariah yaitu sebesar 6,983 sedangkan berdasarkan tabel distribusi $t$ menunjukkan bahwa ( $\mathrm{t}$ hitung $=6,983$ lebih besar dari $\mathrm{t}$ tabel $=1,671$ ) dengan tarap signifikan 0,05 yang menunjukkan bahwa hipotesis 1 (satu) diterima karena terdapat pengaruh yang signifikan antara variabel tingkat bunga dengan variabel kinerja BNI Syariah. 
b. Hipotesis 2: Nilai larangan dalam Al-Qur'an berpengaruh terhadap kinerja BNI Syariah

Hasil pengujian outer model yang telah dilakukan menunjukkan bahwa variabel nilai larangan dalam Al Quran dapat mempengaruhi variabel kinerja BNI Syariah yaitu sebesar 2,857 sedangkan berdasarkan tabel distribusi $\mathrm{t}$ menunjukkan bahwa ( $\mathrm{t}$ hitung $=2,857$ lebih besar dari $t$ tabel $=1,671$ ) dengan taraf signifikan 0,05 yang menunjukkan bahwa pada hipotesis 2 (dua) diterima karena terdapat pengaruh yang signifikan antara variabel nilai larangan dalam Al Quran dengan variabel kinerja BNI Syariah.

\section{c. Hipotesis 3: Tingkat bunga berpegaruh terhadap kinerja BNI Syariah}

Hasil pengujian outer model yang telah dilakukan menunjukkan bahwa hubungan variabel tingkat bunga memiliki pengaruh antara variabel nilai larangan dalam Al Quran sebesar 4,530. Sedangkan berdasarkan tabel distribusi $\mathrm{t}$ menunjukkan bahwa $(\mathrm{t}$ hitung $=4,530$ lebih besar dari $\mathrm{t}$ tabel $=$ 4,530 dengan taraf signifikan 0,05 yang menunjukkan bahwa pada hipotesis 3 (tiga) diterima karena terdapat pengaruh yang signifikan antara variabel tingkat bunga dengan variabel nilai larangan dalam Al Quran.

\section{KESIMPULAN}

Nilai larangan dalam Al-Qur'an berpengaruh terhadap tingkat bunga. Hal ini menunjukkan bahwa variabel nilai larangan dalam Al-Quran dengan variabel tingkat bunga berpengaruh signifkan. Hal ini dikarenakan Bank BNI Syariah Cabang Makassar melakukan segala kegiatan maupun transaksinya sesuai dengan Al Quran dan Hadist.

Nilai larangan dalam Al Quran berpegaruh terhadap kinerja BNI Syariah. Hal ini menunjukkan bahwaantara variabel nilai larangan dengan variabel kinerja BNI Syariah berpengaruh signifikan. Hal ini dikarenakan cara kerja atau pengelolaan perusahaan di Bank BNI Syariah sesuai dengan Al Quran dan Hadist.

Tingkat bunga berpengaruh terhadap kinerja BNI Syariah. Hal ini menunjukkan bahwa antara variabel tingkat bunga dengan variabel kinerja BNI Syariah berpengaruh signifikan. Hal ini dikarenakan dengan adanya 
kenaikan tingkat bungamaka akan konvensional dari pada di bank syariah diikuti oleh naiknya suku bunga karena bunga simpanan di bank simpanan dan suku bunga pinjaman konvesional naik yang pada akhirnya pada bank konvensional. Sehingga tingkat pengembalian yang akan orang akan cenderung untuk diperoleh oleh nasabah penyimpan menyimpan dananya di bank dana akan mengalami peningkatan.

\section{DAFTAR PUSTAKA}

Afandi, M. Yazid. 2009. Fiqh Muamalah dan Implementasinya dalam Lembaga Keuangan Syariah, Yogyakarta. Logung Pustaka.

Antonio Muhammad Syafi'i. 2001. Bank Syariah dari Teori ke Praktik. Jakarta. Gema Insani. 1999. Bank Syariah, Wacana Ulama dan Cendekiawan. Jakarta. Tazkia Institut dan Bank Indonesia.

Azzam, Abdul Azis Muhammad. 2010. Fiqh Muamalah Sistem Transaksi dalam Fiqh Islam. Jakarta. AMZAH.

Eko, Waluyo. 2014. Makalah Sistem Bagi Hasil dalam Perbankan Syariah. Websitehttp://ekowaluyoekonommuda.blogspot.co.id/2014/03/makal ahsistem-bagi-hasil-dalam.html. (11 Januari 2016)

Farida, Ariani. 2012. Pengertian Bunga Menurut Islam. Website http://fhariedharossbone.blogspot.co.id/2012/10/pengertian-bunga-menurut-islam.html. (11 Januari 2016)

Gustiviana. 2011. "Sistem Bagi Hasil Perbankan Syariah". http://gustiviana.blogspot.co.id/2011/12/sistem-bagi-hasil-perbankansyariah.html. (28 Januari 2016)

Husnah. 2011. Pengaruh Suku Bunga, Inflasi dan PDRB terhadap Permintaan Kredit Non-Konsumtif pada PT. BNI Makassar. Penelitian. Makassar. UIN Makassar.

Iqbal Qureshi Anwar. 1985. Islam dan Teori Pembangunan Uang. Jakarta. Tintamas

Lina, Anniswah. 2011. Pengaruh Tingkat Suku Bunga Dan Bagi Hasil Terhadap Volume Deposito Mudharabah (Studi Pada Bank Muamalat Indonesia Tahun 2009 - 2011). Penelitian. IAIN Walisongo Semarang.

Mallaweang, Abdul Rahim. 2013. Bankdan Lembaga Keuangan Syariah Non Bank. Makassar. Gunadarma Ilmu.

Muhammad, Netajulah Shiddiqi. 1986. Pemikiran Ekonomi Islam. Jakarta. LIPPM.

Nopirin. 1993. Ekonomi Moneter Buku 1 (Edisi Keempat). Yogyakarta. BPFE.

Sadono, Sukirno. 2009. Mikro Ekonomi Teori Pengantar (Edisi etiga). Jakarta. Rajawali Pers.

Suhendi, Hendi. 2010. Fiqh Muamalah. Jakarta. RajaGrafindo Persada. 